PUSTABIBLIA: Journal of Library and Information Science

ISSN 2549-3493 (Print); ISSN 2549-3868 (Online)

DOI: http://dx.doi.org/10.18326/pustabiblia.v4i2.283-306

SK Dirjen Risbang-Kemristekdikti No 23/E/KPT/2019 (Peringkat 4 SINTA)

\title{
Strategi Promosi E-Commerce Toko Buku Togamas dalam Masyarakat Virtual
}

\author{
Handiawan Angling Prayuda ${ }^{1^{*}}$; Sri Rohyanti Zulaikha ${ }^{2}$ \\ ${ }^{1}$ Konsentrasi Ilmu Perpustakaan dan Informasi, Pascasarjana \\ UIN Sunan Kalijaga Yogyakarta \\ ${ }^{2}$ Prodi Ilmu Perpustakaan dan Informasi, UIN Sunan Kalijaga \\ Yogyakarta \\ ^Email: yudhahandi03@gmail.com
}

\begin{abstract}
E-commerce is the most popular method or means to buy and sell today. One of the products sold is the book. Togamas as distributor selling book responds to the phenomenon by creating a website to facilitate the online buying process. The problem formulation in this study is how the strategy of promoting e-commerce Togamas bookstore in a virtual society. The purpose of this writing is to describe the e-commerce promotional strategy of the Togamas bookstore. The research methods used are qualitative descriptive. The collection of data used is observation on the website of Togamas bookstore. The analysis knife used in this research is data reduction, data presentation, and withdrawal of conclusions. The result of this writing is Togamas bookstore is able to membranding itself in accordance with the tag line sure Ori (original), definite discount, warranty, and free is very attached to the Togamas bookstore. The implications given online bookstores against virtual communities or especially consumers at online bookstores bring many implications that are positive value i.e. ease of transaction, share knowledge and selective buying. But there are some things that have to be repaired. For example, the use of ratings or reviews contained in Togamas websites does not work properly.
\end{abstract}

Keywords: e-commerce, togamas, strategy, virtual society 


\begin{abstract}
Abstrak
E-Commerce merupakan metode atau sarana promosi jual beli paling populer saat ini. Salah satu produk yang dijual adalah buku. Togamas sebagai distributor penjualan buku merespon fenomena tersebut dengan membuat website guna mempermudah proses jual-beli secara online. Rumusan masalah dalam penelitian ini adalah bagaimana strategi promosi e-commerce toko buku togamas dalam masyarakat virtual. Tujuan penulisan ini untuk mendeskripsikan strategi promosi e-commerce toko buku togamas. Metode penelitian yang digunakan adalah deskriptif kualitatif. Pengumpulan data yang digunakan adalah observasi pada website toko buku togamas. Pisau analisis yang digunakan dalam penelitian ini yakni reduksi data, penyajian data, dan penarikan kesimpulan. Hasil penulisan ini yakni toko buku togamas mampu membranding dirinya sesuai dengan tag line pasti ori (original), pasti diskon, bergaransi, dan gratis sangat melekat pada toko buku togamas. Implikasi yang diberikan toko buku online terhadap masyarakat virtual atau khususnya konsumen pada toko buku online membawa banyak implikasi yang bernilai positif yaitu kemudahan transaksi, share knowledge dan selektif membeli. Namun ada beberapa hal yang memang harus diperbaiki. Sebagai contoh misalnya, penggunaan rating atau ulasan yang terdapat dalam website togamas tidak berfungsi sebagaimana mestinya.
\end{abstract}

Kata Kunci: e-commerce, togamas, strategi, masyarakat virtual.

\title{
Pendahuluan
}

Era Modern seperti sekarang menutut semua kegiatan berbalut dengan teknologi. Kemajuan teknologi yang begitu pesat di berbagai sektor pekerjaan manusia dirasa cukup begitu membantu pekerjaannya. Teknologi ibarat sebuah pakaian dalam era saat ini, dimana dengan teknologi semua ranah bidang pekerjaan dapat terjamah dan mempercepat proses kegiatan. Salah satunya dalam hal jual beli barang seperti jual beli buku menggunakan website sebagai wadah untuk promosi. 


\section{Gambar 1 Hasil Survei APJII Tahun 2018}

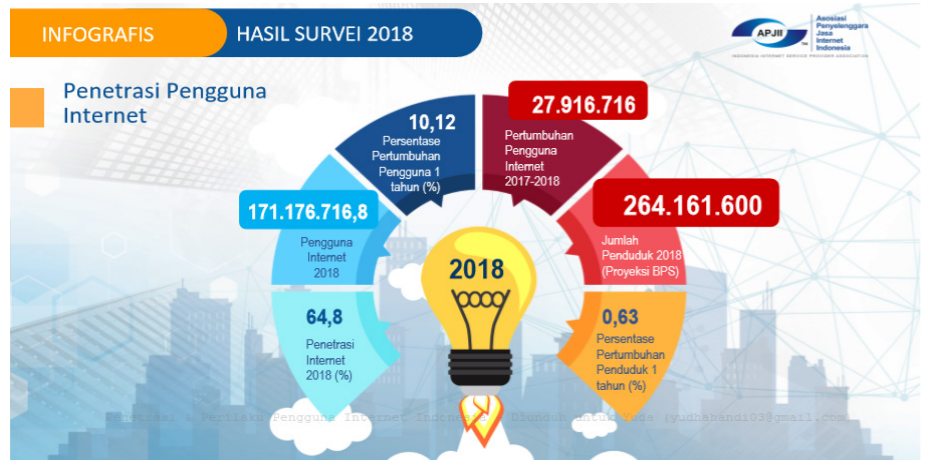

Sumber: Hasil Survei Asosisasi Penyelenggara Jasa Internet Indonesia tahun 2018

Di Indonesia, penggunaan internet per tahunnya terus mengalami peningkatan yang signifikan. Hasil survei Asosiasi Penyelenggara Jasa Internet Indonesia (APJII) tahun 2018 diketahui bahwa jumlah pengguna internet di Indonesia sebanyak 171.176.716,8 juta dan penetrasi pengguna intenetnet sebanyak 64,8\% dengan jumlah penduduk Indonesia sebanyak 264.161.600 juta. Selain itu pertumbuhan pengguna per tahunnya mengalami peningkatan sebesar 10,12\% dengan jumlah pengguna sebanyak 277.916.716 juta dari tahun sebelumnya.

Berkaca pada fenomena maraknya penggunaan internet, tidak menutup kemungkinan buku juga dapat dijual dalam berbagai metode penjualan, bisa menggunakan cara konvensional, lelang, melaui iklan website, dan lain sebagainya. Dengan adanya website sebagai wadah penjualan, konsumen diuntungkan dengan hanya membutuhkan koneksi internet untuk mencari buku yang mereka butuhkan. Mayoritas buku yang tersedia di website sebuah toko buku merupakan buku-buku terbaru yang dimiliki. Dari berbagai toko buku di Indonesia, togamas merupakan salah satu toko buku yang berusaha menyesuaikan dengan gaya atau tren konsumen dalam

${ }^{1}$ APJII, "Laporan Survei Penetrasi \& Profil Pengguna Internet Indosesia Tahun 2018”, dalam https://apjii.or.id/content/read/39/410/Hasil-Survei-Penetrasi-dan-Perilaku-Pengguna-InternetIndonesia-2018, diakses tanggal 11 November 2019 pukul 17:31 WIB. 
mencari dan berbelanja buku yang mereka butuhkan. Tren tersebut identiktik dengan sebutan e-commerce.

Selain menampilkan berbagai macam genre buku, di dalam website toga mas juga menyertakan bagaimana kualitas isi dari setiap buku yang di iklankan dengan bantuan review atau penilaian pemberian rating yang diperoleh dari konsumen yang telah membeli melalui layanan online. Dengan adanya fitur ulasan tesebut, konsumen sangat diuntungkan karena dapat digunakan sebagai pertimbangan untuk memilih sebuah buku yang dibandung dengan adanya ulasan dari konsumen lain tersebut.

E-commerce menjadi tren paling dominan pada era jual beli saat ini. Beragam jenis barang dapat dipromosikan melalui e-commerce tanpa harus memiliki toko berbentuk fisik, sehingga memangkas biaya operasional pemilik lapak tau pelaku usaha. Toko buku toga mas memiliki website yang mencantumkan berbagai macam jenis buku, konsumen dapat mencari dan membeli buku yang tertera di website lengkap dengan deskripsi buku tanpa harus datang langsung ke gerai toko buku togamas.

\section{Gambar 2 Pengguna E-Commerce di Indonesia ${ }^{2}$}

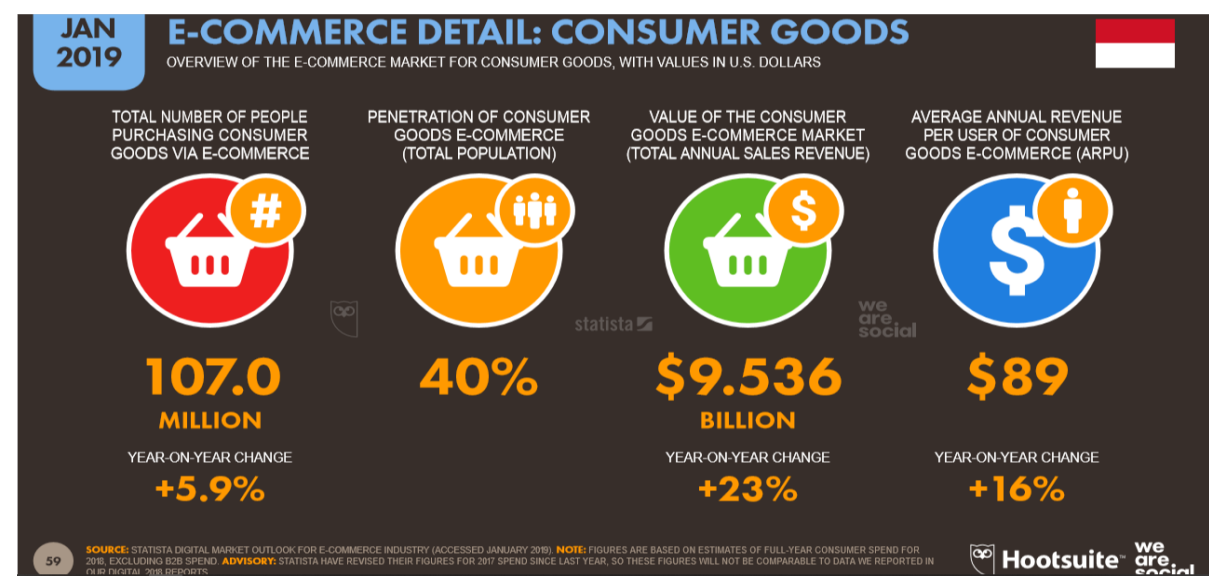

Sumber: We are Social Januari 2019

${ }^{2}$ We Are Social, dalam https://wearesocial.com/global-digital-report-2019, diakses tanggal 11 November 2019 pukul 17:00 WIB. 
Pertumbuhan e-commerce di Indonesia dapat dikatan sangat signifikan, jika melihat Indoensia sebagai negara kepulauan, maka peningkatan transaksi e-commerce kian nyata. Pertumbuhan tersebut didukung dengan data we are social tahun 2019 yang menyatakan bahwa perputaran rupiah dalam e-commerce di Indonesia mencapai Rp 9.536 trilliun dengan presentase $40 \%$. Jumlah tersebut akan terus bertambah seiring dengan meningkatnya penggunaan internet sebagai sarana berbelanja baik melalui smartphone, komputer, penetrasi internet di Indoensia, penggunaan kardu kredit atau debit, serta tingkat kepercayaan masyarakat Indonesia untuk berbelanja online. ${ }^{3}$

\section{Tinjauan Pustaka}

\section{a. Kajian Pustaka}

Penelitan yang senada dengan topik strategi promosi e-commerce telah banyak dilakukan, tetapi belum ada yang membahas tentang implikasinya dalam masyarakat virtual sebagai pengguna atau user atas keberadaan toko buku online atau virtual. Penelitan sebelumnya antara lain sebagai berikut. Pertama, penelitian yang dilakukan oleh Ryan Pratama Sutanto (2017) mahasiswa Desain Komunikasi Visual, Universitas Kristen Petra Surabaya dengan judul "Studi Kasus Website Gramedia sebagai Media Online untuk Membeli Buku”. Tujuan dari penelitian ini adalah memunculkan desain toko buku online sejenis yang bisa mengadopsi dan teknologi berbasis internet dan web sebagai portal transaksi. ${ }^{4}$ Metode yang digunakan yakni peneliti sebagai user yang secara langsung mencoba dan memanfaatkan langsung website toko buku gramedia. Hasil dari penelitian ini yakni perubahan transaksi pembelian buku yang semula konvensional kini beralih pada pembelian secara online hanya dengan melalui website seluruh proses pembelian buku dapat dilakukan. Perbedaan penelitian ini dengan penelitian yang dilakukan oleh penulis terletak pada strategi yang digunakan dalam proses promosi produk.

\footnotetext{
${ }^{3}$ Novita Retnowati, "Pengaruh E-Wom (Electronic Word of Mouth) Pada Situs Social Commerce Terhadap Niat Beli Generasi X, Y, dan Z”, Thesis (Surabaya: Institut Sepuluh November, 2017), 1.

${ }^{4}$ Ryan Pratama Sutanto, "Studi Kasus Website Gramedia sebagai Media Online untuk Membeli Buku”, Nirmana, Universitas Kristen Petra Surabaya, Vol. 17, No. 1, (Januari 2017), 37-41.
} 


\section{b. Kajian Teori}

\section{1) New Media}

Perubahan akan kebutuhan manusia dari zaman primitif hingga saat ini terus mengalami kemajuan terutama dalam hal teknologi. Teknologi menjadi media yang terus beriringan dengan kegiatan manusia. Hingga memasuki era modern seluruh rangkaian kegiatan manusia dibalut dengan teknologi (internet) sebagai sarana baru media berkomunikasi. Berbagai media komunikasi bermunculan seperti facebook, twiter, Instagram, website dan lain sebagainya. Karateristik New Media dapat di definisikan menjadi beberapa jenis yakni digital, pro-active, visible, real-time, and memory, serta ubiquitous network. ${ }^{5}$

\section{2) E-Commerce}

E - commerce adalah singkatan dari perdagangan elektronik dan melayani perdagangan barang dan jasa melalui media elektronik seperti internet, seluler atau jaringan komputer lainnya. Ini melibatkan penggunaan Teknologi Informasi dan Komunikasi dan Transfer Dana Elektronik dalam membuat perdagangan antara konsumen dan organisasi, organisasi dan organisasi atau konsumen dan konsumen. Dengan meningkatnya penggunaan internet di seluruh dunia, Electronic Data Interchange (EDI) juga telah meningkat dalam jumlah yang sangat banyak dan karenanya telah mengembangkan e - commerce dengan bazaar internet virtual yang subur di dunia digital yang secara tepat disebut sebagai e-mail. ${ }^{6}$

Adapun beberapa komponen e-commerce sebagai berikut:

a) Electronic Data Interchange

Electronic DataInterchangeatau biasa disingkat dengan EDI merupakan pertukaran dokumen yang biasanya dilakukan antara perusahaan satu dengan perusahaan lainya dengan bentuk dokumen elektronik.

${ }^{5}$ Thurau et. al, "The Impact of New Media on Customer Relationships", Journal of Service Research, Vol. 13, No. 3, (Agustus 2010), 312.

${ }^{6}$ Mohd Fawzy A B, Sharuddin S H, Rajagderan S, Wan Zulkifly W Z, "E-commerce adoption and an analysis of the popular e-commerce business sites in Malaysia", Journal of Internet Banking and Commerce, aOttawa, Vol. 23 No. 1, (Apr 2018), 2. 
Dokumen yang paling umum dipertukarkan melalui EDI adalah pesanan pembelian, faktur, dokumen status pengiriman barang dan lain sebagainya. Dengan mengunakan dokumen elektronik ini tentu memiliki beberapa keuntungan antara kedua pihak diantaranya yaitu kecepatan proses pertukaran, pengurangan kesalahan, dan meningkatkan hubungan antara kedua bisnis.?

b) Digital Currency

Mata uang digital atau bisa dikenal dengan digital currency merupakan salah satu komponen yang ada pada e-commerce pada saat ini. digital currency ini juga bukan merupakan hal yang baru karena telah digunakan oleh sistem perbankan dalam beberapa dekade. Manfaatnya memungkinkan user untuk memindahkan dananyasecara elektronik dalam lingkungan kerja tertentu. bahkan dalam binis e-commerce saat ini telah menjadikan uang eletronik sebagai salah satu alat yang sangat penting untuk keberlangsungan dalam proses bisnis. Beberapa contoh uang elektronik seperti go-pay, ovo, dan e-money.

c) Electronic Catalogs

Katalog telah dicetak di atas kertas selama beberapa generasi. Baru-baru ini, katalog elektronik pada DVD (atau CD-ROM) dan di Internet telah mendapatkan popularitas. Katalog elektronik (e-katalog) terdiri dari basis data produk yang menjadi tulang punggung dari dalam situs penjualan e-commerce. Tujuanya dari e-katalog untuk mempromosikan berbagai produk atau jasa yang diberikan dengan model tertentu. Konsep katalog yang ditampilkan pada $e$-commerce saat ini sangatlah fleksibel dan sangat menarik. ${ }^{8}$

d) Internet dan Extranet

Internet (singkatan dari interconnection-networking) adalah seluruh jaringan komputer yang saling tehubung menggunakan standar sistem global transmission control protocol/internet protocol suite (TCP/IP)

${ }^{7}$ OpenText Corp, EDI Basics: How Successful Businesses connect, communicate, and collaborate, around the word, (opentext, 2017), 4.

${ }^{8}$ Efraim Turban et al., Electronic Commerce 2018, (Springer, 2018), 51. 
sebagai protokol pertukaran paket (packet switching communication protocol) untuk melayani miliaran pengguna di seluruh dunia. Sedangkan extranet merupakan jaringan yang pribadi yang mengunakan protokol internet dan sistem telekomunikasi publik untuk membagikan informasi dengan memiliki privasi untuk mengirimkan dokumen ke suplayer, vendor, atau mitra. ${ }^{9}$ Perbedaan antara kedua komponen yaitu yaitu dilihat dari sekala komunikasi atau akses yang berbeda.

Di Indonesia sendiri terdapat berbagai macam model e-commerce yang digunakan dan disesuaikan dengan tujuan dan pasar yang masuk dalam prioritas pemasaran produk setiap pelaku e-commerce. Pertama, Classifield/ listing/iklan baris merupakan model e-commerce yang paling sederhana dan cocok diterapkan di negara yang sedang berkembang, karena website yang digunakan tidak memfasilitasi transaksi online dan juga pihak penjual dapat menjual barang dagangan mereka kapan saja secara gratis. Biasanya metode yang digunakan dalam metode ini menggunakan sistem pembayaran COD (cash on delivery). Kedua, Marketplace C2C (Consumer to Consumer) merupakan model yang sudah dilengkapi dengan proses transaksi secara online dalam website. Kategori website yang masuk dalam ranah ini dapat diihat dari fasilitas website yang mencover seluruh kegiatan jual beli hingga transaksi, selain itu pihak penjual juga berasal dari perseorangan bukan dari lapak yang sudah memiliki branding. Model seperti ini cenderung cocok bagi pelaku e-commerce yang benar-benar ingin serius dalam berjualan online dan memiliki ketersediaan barang dagangan dalam skala besar.

Ketiga, Shopping mall merupakan metode yang hampir mirip dengan marketplace dimana sebagai pihak vendor e-commerce biasanya menetapkan proses verifikasi yang ketat untuk bergabung di dalamnya. Selain itu juga harus memiliki branding yang cukup tenama dikalangan masyarakat. Keempat, Toko online B2C (Business to Consumer) merupakan model yang digunakan oleh pelaku usaha online yang memiliki website sendiri untuk

${ }^{9}$ Ezekiel A. Setiawan, "Internet, intranet, extranet: pondasi e-business mendatang: perlu ditopang pengetahuan/kesadaran akan Internet Security;” Buletin Informatika, Vol. 4 No.1 (2015), 20. 
mempromosikan produk-produknya secara online sehingga otoritas tertinggi dalam pengelolaan website tersebut dipegang oleh pemilik atau pelaku usaha itu sendiri. Kelima, Toko Online di Media Sosial merupakan model dimana pelaku usaha online tidak menggunaka website, bergabung dengan vendor e-commerce tetapi mereka melakukan proses jual beli menggunakan media sosial seperti facebook, Instagram yang dipandang metode jual beli paling mudah dan gratis. Model seperti ini memiliki keterbatasan dalam hal tampilan karena pelaku uasaha tidak dapat menentukan atau membuat tema sesuai dengan keinginannya. ${ }^{10}$

\section{3) Manfaat E-Commerce}

Manfaat akan hadirnya e-commerce cukup dirasakan oleh konsumen terutama pada masing-masing individu. Dampak positif dan negatif akan hadirnya e-commerce yakni sebagai berikut:

a) Manfaat positif.

- Kemudahan dalam mempromosikan suatu barang sangat mudah dirasakan oleh para penjual karena hadirnya berbagai media sosial sekaligus mengurangi biaya promosi yang biasa dilakukan sebelum adanya e-commerce;

- Aktivitas jual beli dapat terkontrol dengan baik setelah adanya e-commer$c e$, selain itu dapat mengurangi atau mencegah kehilangan barang;

- Memudahkan pencarian produk terutama bagi konsumen;

- Jam operasional toko juga lebih fleksibal atau bahkan buka hingga 24 jam karena tidak memerlukan toko dalam bentuk fisik.

b) Manfaat Negatif

- Tingginya modus penipuan karena konsumen tidak bertransaksi secara langsung;

- Kualitas barang juga dipertanyakan karena barang hanya berupa gambar berbeda ketika melakukan proses jual beli konvensional. ${ }^{11}$

22-24.

${ }^{10}$ Adi Sulistyo Nugroho, E-Commerce: Teori dan Implementasi (Yogyakarta: Ekuilibra, 2016),

${ }^{11}$ Adi Sulistyo Nugroho, E-Commerce: Teori dan ..., 9. 


\section{4) Promosi}

Promosi merupakan serangkaian kegiatan untuk memasarkan suatu produk kepada konsumen guna menarik minat membeli produk tersebut dengan menggunakan berbagai media promosi inovatif baik online atau offline. ${ }^{12}$ Selain itu, promosi dapat dimaknai sebagai salah satu bentuk pertukaran informasi searah yang sengaja dibuat untuk mengarahkan seseorang atau organisasi kepada tindakan. ${ }^{13}$ Dalam sebuah organisasi atau lembaga promosi umum digunakan sebagai rancangan untuk menggambarkan tahapan sebuah organisasi dalam beroperasi guna mencapai tujuannya. ${ }^{14}$

\section{5) Strategi}

Strategi berasal dari kata Yunani "strategia" (stratos=militer dan ag=memimpin), yakni suatu bakat atau seni untuk menjadi seorang pemimpin. ${ }^{15}$ Dalam Kamus Besar Bahasa Indonesia "strategi merupakan ilmu dan seni yang menggambarkan seluruh sumber daya bangsa guna melaksanakan kebijaksanaan tententu disaat kondisi perang dan damai; ilmu dan seni untuk memipin bala tentara guna menghadapi lawan di medan pertempurandalam segala kondisi yang menguntungkan; rencana yang matang terkait kegiatan untuk mencapai sasaran khusus". ${ }^{16}$

Dalam perkembangannya, stetegi merupakan ilmu pengetahuan yang dapat dipelajari. Seperti halnya dalam kegiatan promosi yang merupakan kegiatan untuk mempengaruhi orang lain dengan beragam cara untuk mencapai tujuan dengan efektif serta efisien. Parameter efisien dan efektif dalam kegiatan promosi tergantung dalam proses dan sumber daya yang dgunakan. Dalam bidang ekonomi, strategi sering kali digunakan oleh

${ }^{12}$ Peattie K., "The Marketing Mix in The Third Age of Computing," Emerald, Volume 15, Issue 3, dalam (https://doi.org/10.1108/02634509710165948), diakses tanggal 20 April 2019, 148.

${ }^{13}$ Basu Swastha dan Hani Handoko, Manajemen Pemasaran Analisis Perilaku Konsumen. (Yogyakarta: BPFE, 1982), 349.

${ }^{14}$ Stanton WJ, Manajemen dan Pemasaran. (Jakarta: Erlangga, 1991), 5.

${ }^{15}$ Fandy Tjipto, Strategi Pemasaran (Yogyakarta: Andi, 1998), 3.

${ }^{16}$ Pusat Bahasa Departemen Pendidikan Nasional, Kamus Besar Bahasa Indonesia, ed. Ke-3 (Jakarta: Balai Pustaka, 2007), 1092. 
pemimpin dalam organisasi atau perusahaan sebagai tindakan yang bersifat representatif dan bentuk upaya merespon kompetitor. Sedangkan pemahaman umum tentang strategi dapat dimaknai sebagai langkah awal untuk menuju target utama yang ingin dicapai. Dengan demikian strategi dapat dipahami sebagai progam yang sengaja dibentuk dan dilakukan dengan tindakan sesuai prosesdur yang telah disusun sedemikian rupa untuk mencapai tujuan.

\section{6) Rencana Strategi}

Strategi pada setiap lembaga organisasi pasti telah direncanakan dengan matang sesuai dengan tujuan yang ingin dicapai di masa mendatang. Hal tersebut juga berlaku di perpustakaan dimana sebagai salah satu lembaga penyedia sumber informasi memiliki rencana dan strategi yang telah dirancang sedemikian rupa untuk mengidetifikasi dan menyediakan produk yang tepat guna bagi pengguna. Beberapa komponen strategi perpustakaan adalah sebagai berikut: ${ }^{17}$

a. Rencana yang disusun harus ringkas, mudah dimengerti, dan mudah diimplementasikan;

b. Fokus terhadap pengidentifikasian pengguna tentang apa saja yang mereka butuhkan dan yang mereka harapkan dari layanan perpustakaan;

c. Berpandangan ke masa depan apa yang akan terjadi selanjutnya.

\section{7) Jenis Strategi}

Dalam melakukan kegiatan promosi di lingkungan perpustakaan, terdapat beberapa hal yang dapat dilakukan, yaitu sebagai berikut: ${ }^{18}$ Pertama, Operational excellence yakni jenis strategi yang difokuskan pada pelayanan kepada pengguna. Contohnya seperti pencarian koleksi dimana pustakawan dapat membantu proses pencarian hingga pengguna menemukan koleksi yang mereka butuhkan. Kedua, Innovative service yakni strategi yang difokuskan pada layanan yang lebih inovatif tertuma layanan kepada pengguna. Contohnya seperti perpanjangan dan pengembalian buku yang

${ }^{17}$ Joseph Matthews, Strategic Planning and Management for Library Managers (London: Libraries Unlimited, 2005), 4.

${ }^{18}$ Ibid., hlm. 43. 
dapat dilakukan dengan memanfaatkan aplikasi mandiri (perpanjangan) dan book drop (pengembalian mandiri).

Ketiga, customer Intimatcy yakni strategi yang difokuskan pada hal privat antara perpustakaan dengan pengguna. Tujuannya agar perpustakaan dan pengguna tidak memiliki jarak sehingga hubungan baik dapat terjalin antar keduanya. Contohnya seperti memberi masukan kepada perpustakaan dalam merekomendasikan koleksi yang akan diadakan oleh perpustakaan.

\section{8) Tahapan Strategi}

J. David Hunger dan Thomas L. Wheelen menjelaskan bahwa terdapat empat elemen dasar dalam manajemen strategis, yakni sebagai berikut: Pertama, pengamatan lingkungan tediri dari pengamatan internal dan eksternal. Pengamatan eksternal dilakukan untuk memahami variabelvariabel (kesempatan dan ancaman) yang tidak dapat diprediksi dan jauh dari jangkauan organisasi. Analisis internal merupakan pemahaman variabel (kekuatan dan kelemahan) di dalam lingkungan organisasi tetapi tidak berada dalam koridor strategi utama.

Kedua, merumuskan strategi dilakukan dalam bentuk pengembangan rencana atau plan baik jangka menenga atau jangka panjang yang dibuat berdasarkan kelemahan dan kekuatan organisasi. Ketiga, implementasi strategi merupakan bentuk realisasi perencanaan dan kebijakan yang telah dibuat dalam bentuk pengembangan program, prosedur, dan anggaran. Keempat, evaluasi dan pengendalian merupakan proses untuk mengawal hasil kerja. ${ }^{19}$

\section{9) Ruang Virtual dan Masyarakat Virtual}

Perubahan-perubahan masyarakat dari zaman primitif sampai saat ini telah menunjukan hal yang signifikan. Teknologi sebagai produk dari pemikiran manusia selama berabad-abad melalui era klasik, modern dan posmodern yang membawa manusia ke dunia baru, dimana kesemuan (virtual) dipahami sebagai realitas. Seperti halnya penggunaan teknologi

${ }^{19}$ J. David Hunger dan Thomas L. Wheelen, Strategic Management and Business Policy, ed. Ke-9 (Pearson: Prentice Hall, 2004), 49. 
sebagai alat bantu untuk menunjang kehidupan sehari-hari telah menjadi kebutuhan primer. Hal ini dapat dilihat dengan berbagai media komunikasi seperti facebook, twitter dan Instagram telah digunakan untuk berkomunikasi tanpa harus bertatap muka. Selain itu juga dari dampak teknologi mulai tumbuh di berbagai sektor dengan adanya perusahan retail yang telah menyediakan berbagai kebutuhan sehari-hari tanpa harus mendatangi toko atau tempatnya.

Semua produk pemikiran ini pada dasarnya disebut dengan ruang virtual yang hadir untuk dikomsumsi masyarakat. kemudian ruang vitual yang diciptakan ini melebur dengan ruang realitas manusia. Ruang virtual diproduksi ketika user bermain game online dengan lawan mainnya, kondisi tersebut sebenarnya sedang terjadi proses teleportasi ke dalam ruang virtual dan sebagai pemain game online sudah kehilangan kontak dengan ruang realitasnya. Secara fisik seorang peman game akan berda dalam situasi da kondisi nyata, namun tanpa sadar, seorang pemain game akan dibawa dalam ruang virtual melalui simulasi environment dalam game tersebut. Termasuk ketika kita sedang memandang layar laptop, berinteraksi melalui media sosial seperti Skype, ruang dimana secara fisik kita berada tersebut sedang di decode - encode menjadi sebuah ruang virtual, dimana lawan interasi kita dalam media sosial tersebut seolah datang dan berbincang langsung dimeja. ${ }^{20}$

Kemudian ruang-ruang ini tentu telah disinggung di atas yang membutuhkan pelaku-pelaku untuk memanfaatkan ruang-ruang tersebut. Untuk itu, adanya minat individual sampai dengan kelompok-kelompok tertentu yang memanfaatkan ruang virtual tersebut tercetuslah satu isitlah yaitu masyarakat virtual. Masyarakat Virtual adalah sebuah kehidupan masyarakat manusia yang tidak dapat secara langsung diinderakan melalui penginderaan manusia, namun dapat dirasakan dan disaksikan sebagai sebuah realitas. Kehidupan semacam ini tentu saja bukanlah kehidupan akhirat manusia, namun merupakan sisi lain kehidupan "masyarakat nyata" yang seperti kita ketahui selama ini. Di mana "masyarakat nyata" lebih

${ }^{20}$ Luri Renaningtyas, Ruang Virtual dan Ruang Realitas, (Universitas Kristen Petra, Desain Komunikasi Visual 2013), 7. 
menekankan pada jalinan kehidupan sosial manusia yang berbasis dan dibangun melalui penginderaan secara langsung. ${ }^{21}$ Maka ruang virtual dan masyarkat virtual tidak dapat dipisahkan satu sama lainnya. Masyarakat disebut dengan masyarakat virtual karena adanya ruang virtual yang menjadi adahnya. Namum, wadah ini tidak akan berjalan dengan baik apabila masyarakat tidak menghendaki untuk menggunakan sehingga dua komponen ini akan saling berkontribusi.

\section{Metode}

Tujuan dari penulisan ini yakni untuk mendeskripsikan strategi promosi e-commerce toko buku togamas. Sedangkan manfaat penulisan ini untuk kalangan kalangan akademisi untuk memberikan pemahaman strategi promosi e-commerce toko buku online. Sedangkan untuk peneliti sebagai sarana pengembangan penerapan keilmuan pada bidang kajian internet dan masyarakat virtual. Adapun manfaat teoritis yang di dapat dari penulisan ini adalah menjadi masukan dan kajian pustaka bagi penulisan selanjutnya terkait strategi promosi e-commerce toko buku Togamas. Berdasarkan pemaparan latar belakang tersebut, penulis ingin mengangkat permasalahan bagaimana strategi promosi e-commerce toko buku togamas dalam masyarakat virtual.

Metode penulisan yang digunakan adalah menggunakan pendekatan kualitatif deskriptif, yakni mendeskripsikan fenomena-fenomena yang ada pada website toko buku togamas. Objek penulisan pada makalah ini adalah toko buku online di Indonesia yang dianggap mewakili e-commerce pada bidang penjualan buku, yaitu toko buku online Togamas. Analisis konten yang digunakan berdasarkan website toko buku togamas. Metode penulisan yang digunakan melalui studi kasus pada beberapa objek penulisan sehingga penulisan didasarkan pada data tertulis berbentuk buku, ensiklopedia, jurnal, atau artikel lepas yang terkait toko buku online dalam masyarakat virtual beserta implikasinya terhadap masyarakat virtual. Objek penulisan pada

${ }^{21}$ Rino Setyadi, “Komunikasi Virtual: Sebuah Keniscayaan Masyarakat Teknologi," dalam http://komunikasi.us/index.php/course/4899-komunitas-virtual-sebuah-keniscayaan-masyarakatteknologi, diakses tanggal 15 Maret 2019 pukul 19:00 WIB. 
penelitian ini adalah toko buku online di Indonesia yang dianggap mewakili e-commerce pada bidang penjualan buku, yakni Togamas.

Pisau analisis yang digunakan dalam penelitian ini adalah (1) reduksi data yakni mengorganisasikan informasi yang diperoleh sesuai dengan topik penelitian, (2) penyajian data yakni tahapan penyerdehanaan data yang telah diperoleh agar dapat dipahami dengan mudah dalam bentuk tulisan naratif, (3) penarikan kesimpulan yakni mendeskripsikan objek tertentu yang dalam bentuk temuan yang sebelumnya belum diketahui sehingga dapat diketahui untuk menjawab permasalahan yang terjadi sebelumnya. ${ }^{22}$

\section{Hasil dan Pembahasan}

\section{a. Toko Buku Toga Mas}

Sejarah Toko Buku Diskon Togamas didirikan tanggal 15 Desember 1990 oleh suami istri Johan Budhie Sava dan Swandayani. Dibangun dengan konsep discount store (diskon seumur hidup), harga buku yang ditawarkan setelah diskon jauh lebih murah dari toko buku modern pada umumnya. ${ }^{23}$ Dimulai dari toko buku kecil dengan jumlah item sekitar 1000 judul buku dan luas toko 50 meter persegi dengan memanfaatkan ruang tamu, rumah tinggal di kota Malang, Jawa Timur. Usaha Toko Buku Diskon ini berkembang dengan pesat, tumbuh dan menjadi besar. Saat ini, Toko Buku Diskon Togamas di kota Malang telah menempati gedung sendiri 3 lantai dengan luas 1200 meter persegi.

Antusiasme pasar yang terus berkembang serta potensi yang menjanjikan pada akhirnya Johan Budhie Sava membuka kesempatan kepada investor lain untuk ikut mengembangkan usaha toko buku dengan konsep partnership (kemitraan). Program ini membidik pasar di wilayah kota tingkat 2 (kabupaten) selain terus mengembangkan toko mandiri. Saat ini Togamas sudah membuka lebih dari 20 gerai di seluruh Jawa dan Bali, tidak menutup

\footnotetext{
${ }^{22}$ M. Djunaedi Ghony dan Fauzan Almansur, Metodologi Penelitian Kualitatif (Yogyakarta: Ar-Ruzz Media, 2014), 306. WIB.

${ }^{23}$ Togamas, dalam http://togamas.co.id/views-aboutus, diakses tanggal 15 Maret 2019 18:20
} 
kemungkinan jaringan Toko Buku Diskon Togamas akan merambah pulaupulau di luar Jawa. Visi dari toko buku Togamas, yaitu terus dikembangkan hingga menjadi jaringan toko buku harga murah dan menjadi pasangan alamiah dunia pendidikan (Natural Partner for Educational Development). Sedangkan misi toko buku togamas, yaitu membangun jaringan Toko Buku Diskon yang efektif dan efisien. Memanfaatkan teknologi modern dan komputerisasi. Dukungan sumber daya manusia yang professional dan handal. Berpegang teguh pada komitmen "BERPADU MEMBANGUN MASYARAKAT BERPENGETAHUAN”."

\section{b. Strategi Promosi Togamas}

Sebagai toko buku retail yang memiliki jaringan toko buku hampir tersebar di berbagai wilayah, Togamas dan terus berusaha berinovasi untuk bersaing dengan para kompetitor, Togamas online hadir menjawab berbagai tantangan. Slogan yang dimiliki Togamas dengan bunyi pasti ori (original), pasti diskon, bergaransi, dan gratis sampul menjadi tag line utama dari laman home websitenya.

Gambar 3, secara umum memiliki tampilan yang lebih variatif pada banyaknya sub menu kategori buku sehingga terkesan kurang sederhana. Karakter webisite yang diterapkan Togamas online ini tidak jauh berbeda dari apa yang diterapkan para kompetitor. Selain itu gulir iklan juga tidak ada ataupun menu kekinian seperti flash sale juga tidak terdapat pada laman Togamas. Ciri khas dari tampilan website togamas adalah adanya ulasan atau rating pada masing-masing buku yang mereka posting pada laman website mereka. Selain itu market togamas menyasar semua kalangan usia, dengan adanya pilihan menu kategori favorit di tampilan laman utama.

${ }^{24}$ Ibid. 


\section{Gambar 3 Laman Home Togamas Online ${ }^{25}$}

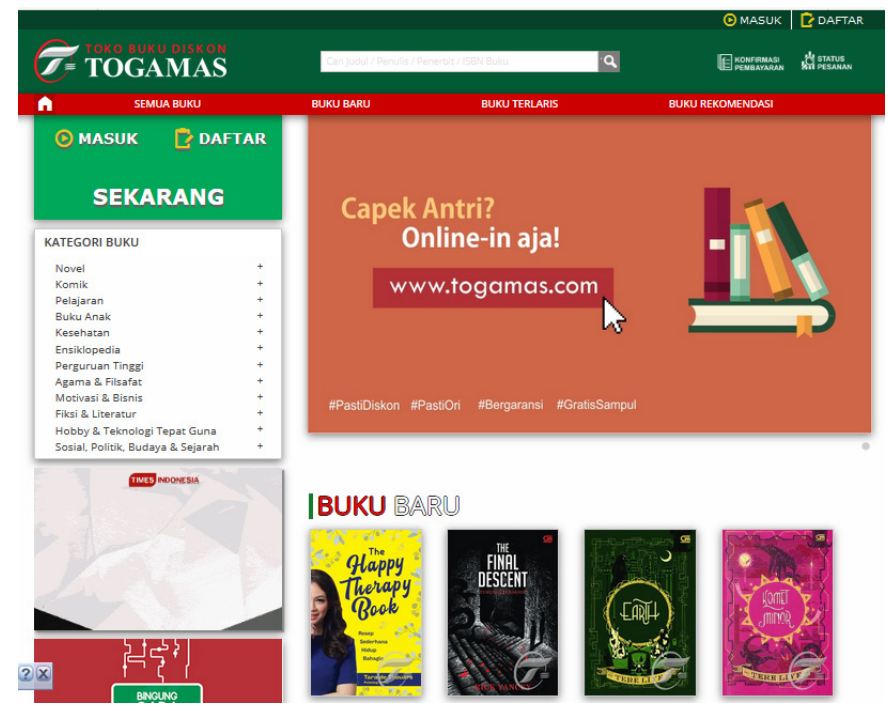

Sumber: Website Togamas

\section{Gambar 4 Review atau Rating Buku ${ }^{26}$}

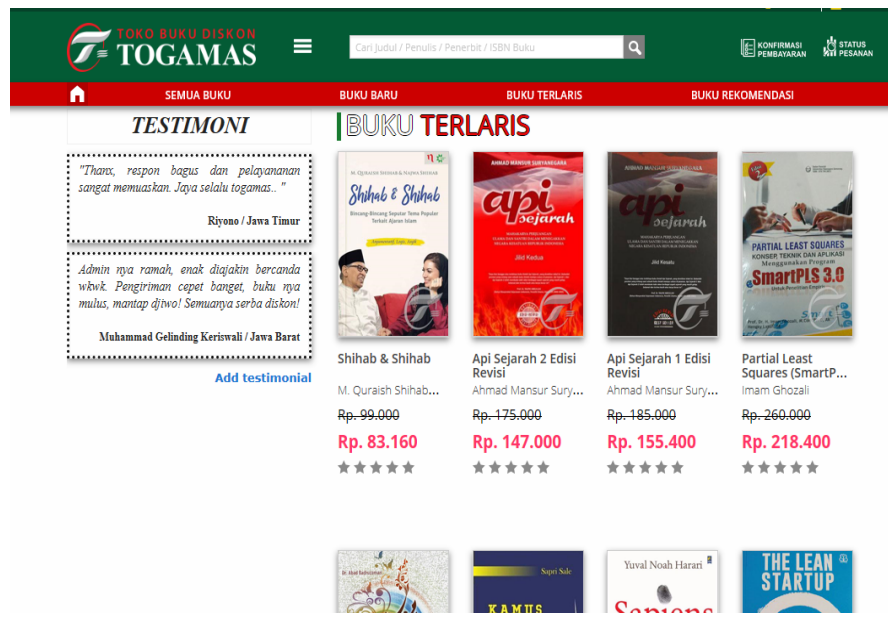

Sumber: Website Togamas

${ }^{25}$ Togamas, dalam https://togamas.com/ diakses tanggal 15 Maret 2019 pukul 19:16 WIB.

${ }^{26}$ Ibid. 
Pada gambar 4 berisi tentang ulasan setiap buku yang diperoleh berdasarkan penilaian dari para konsumen online Togamas. Dengan adanya fitur rating atau ulasan tersebut, konsumen sedikit diuntungkan karena memiliki tambahan saran atau pertimbangan untuk membeli buku yang mereka butuhkan berdasarkan ulasan tersebut. Hal tersebut salah satu strategi togamas dalam mempromosikan buku yang mereka jual secara online melalui website. Akan tetapi dalam praktiknya, fitur ulasan tersebut tidak berjalan. Mayoritas dari seluruh buku yang dimuat dalam website togamas tidak memilik rating. Hal tersebut menjadi evaluasi pihak Togamas khususnya IT untuk memperbaiki fitur tersebut agar berfungsi dengan semestinya.

\section{Gambar 5 Menu Kategori Favorit ${ }^{27}$}

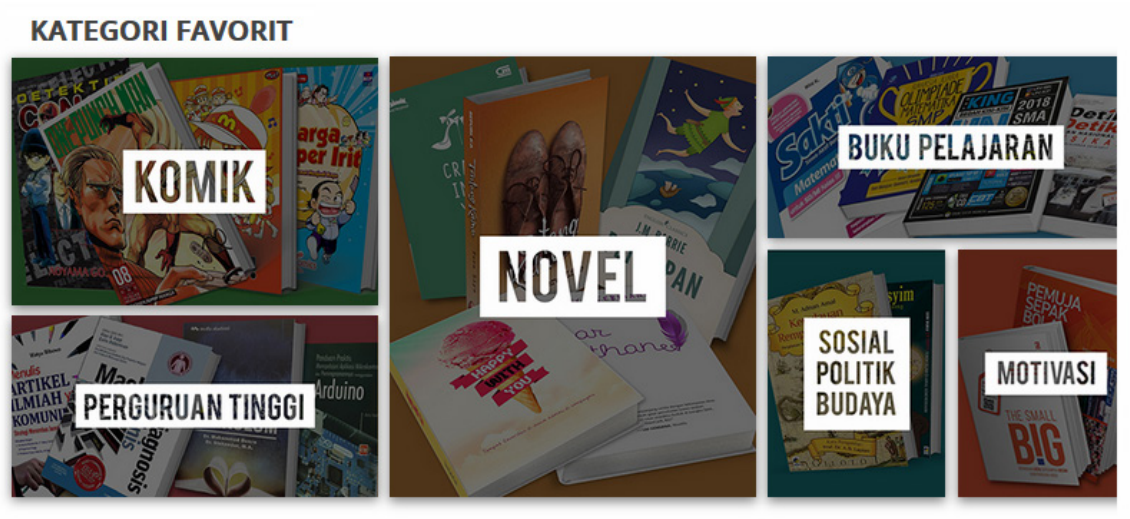

Sumber: Website Togamas

Gambar 5 dapat diinteprtasikan sebagai tampilan menu yang menyajikan koleksi-koleksi togamas untuk memudahkan pencarian buku berdasarkan kelas atau bidang keilmuan. Fitu ini juga membantu konsumen dengan cepat memperoleh buku yang diminatinya.

\section{${ }^{27}$ Ibid.}




\section{Gambar 6 Tampilan Produk dan Transaksi ${ }^{28}$}

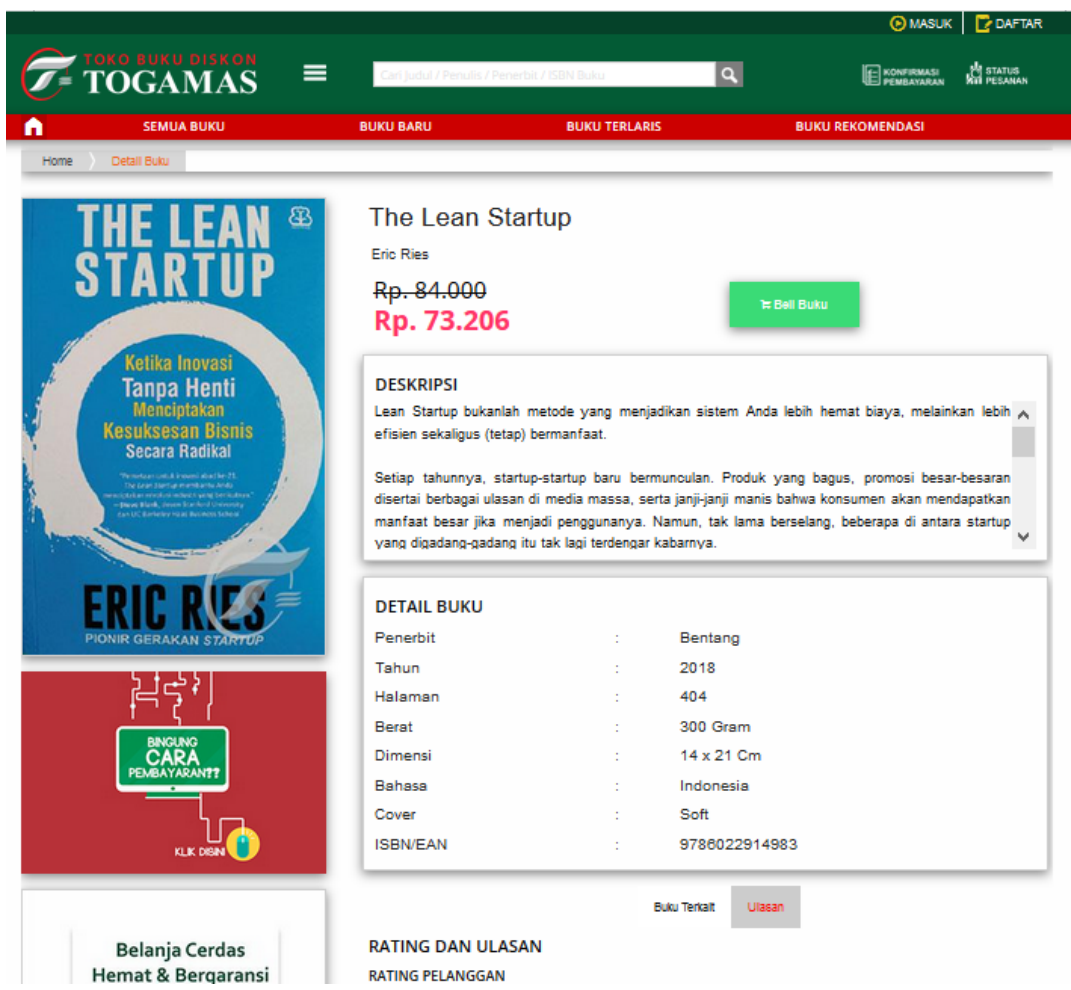

Sumber: Website Togamas

Berdasarkan gambar di atas, Togamas menerapkan kelengkapan dari detail isi produk atau buku yang ada. Sesuai dengan tag line dari Togamas, harga produk pun sudah mengalami diskon, hal ini yang menjadi poin lebih dari Togamas. Secara tipologi Togamas lebih mengarah kepada pembeli yang "gila" diskon, sehingga seluruh produk yang dijual Togamas mendapatkan potongan harga. Tentu dengan adanya diskon tersebut sangat menguntungkan konsumen dan mempunyai opsi untuk membeli buku murah dan original. Kelemahan dari Togamas berupa tidak adanya kolom ulasan, rating, komentar langsung, maupun live chat. Secara keseluruhan

${ }^{28}$ Ibid. 
dapat disimpulkan bahwa, Togamas mampu menganalisa atau sesuai dengan tipologi kompetitif yang dibutuhkan oleh kosumen, dalam hal ini masyarakat virtual yang tertarik dengan harga. Fokusnya pemburu diskon buku maka berbagai inovasi telah dilakukan dengan maksimal.

\section{c. Implikasi dalam Masyarakat Virtual}

Berdasarkan pada pembahasan sebelumnya dapat diketahui implikasiimplikasi apa saja yang dihadapi oleh masyarakat virtual dengan adanya toko buku online tersebut, antara lain sebagai berikut.

\section{1) Kemudahan Transaksi}

Salah satu kemudahan adanya toko buku online terhadap masyarakat virtual adalah adanya kemudahan transaksi yang meliputi:

a) Metode Pembayaran

Beragamnya cara pembayaran ditawarkan dari masing-masing toko buku online, baik melalui metode transfer, e-banking, maupun e-money, hal ini membawa berbagai implikasi terhadap masyarakat virtual berupa minimnya bertransaksi menggunakan uang konvensional. Implikasi negatifnya dimungkinkan sistem keamanan perbankan yang masih lemah.

b) Pengiriman

Jasa pengiriman juga beragam dari masing-masing toko buku online, hal ini memungkin konsumen maupun masyarakat virtual memilih banyak opsi dan tidak perlu repot-repot ke toko buku hanya sekedar membeli satu buku saja misalnya. Kendalanya ketika alamat dan barang yang dikirimkan tidak sesuai, karena masing-masing toko buku online menggunakan jasa pengiriman dari eksternal mereka.

c) Asuransi atau Garansi

Selain menyediakan beragam cara pembayaran dan jasa pengiriman, asuransi atau garansi juga diberikan oleh masing-masing toko buku online sehingga ketika ada kerusakan atau tidak sesuai konsumen dapat mengembalikan atau keuhan ke masing-masing toko buku online. 


\section{2) Share Knowlegde}

Berbagi pengetahuan dalam konteks ini dapat berupa berbagi review atau ulasan mengenai produk atau buku tersebut, antara lain sebagai berikut:

a) Berbagi Ulasan Buku atau Produk

Ulasan sangat penting bagi masyarakat virtual khususnya konsumen yang akan membeli produk tersebut, terlebih dengan adanya sinkronisasi dengan Goodreads menjadikan ulasan menjadi menarik. Kendalanya ketika ada ulasan yang tidak berkualitas atau akun palsu atau robot.

b) Berbagi Buku atau Produk Favorit di Media Sosial

Mudahnya membagikan buku yang disenangi melalui berbagai platform media sosial yang ada dan terintegrasi seperti facebook, twitter, dan Instagram. Masing-masing toko buku online mempunyai integrasi yang berbeda terkait fitur bagikan buku atau produk favoritnya.

c) Testimoni

Selain ulasan, ada pula testimoni, jika ulasan lebih mengulas tentang produk, testimoni lebih kepada kepuasan pelayanan atau pembelian. Kendala atau negatifnya juga hampir mirip dengan ulasan, yakni ketika memberikan testimony palsu. Berikut contoh testimoni:

\section{Gambar 7 Contoh Testimoni di Togamas ${ }^{29}$}

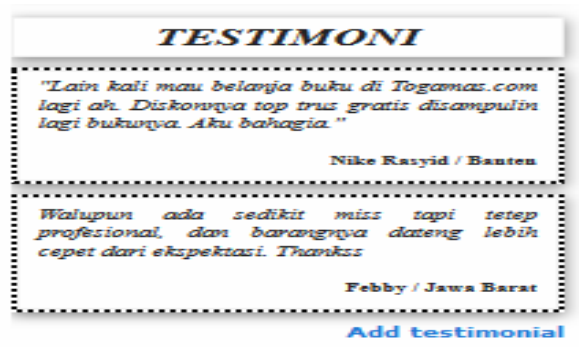

Sumber: Website Togamas

${ }^{29}$ Togamas, dalam https://togamas.com/ diakses tanggal 15 Maret 2019 pukul 20:15 WIB. 


\section{3) Selektif Membeli}

Masyarakat virtual kian mudah dengan adanya berbagai pilihan toko buku online sehingga masyarakat virtual menjadi lebih selektif dalam membeli. Berikut beberapa keuntungan yang didapatkan:

a) Dimudahkan dengan Buku Terkait

Ketika masyarakat virtual atau konsumen membeli buku, toko buku online mampu menawarkan buku-buku terkait dengan topik, tema, ataupun pengarangnya.

b) Membandingkan Harga

Bagi masyarakat virtual khususnya konsumen dengan hadirnya transparansi harga memudahkan dalam membandingkan produk atau buku yang paling murah. Namun tetap dengan memperhatikan syarat dan ketentuan yang berlaku serta ketentuan jasa pengiriman yang berlaku.

Secara keseluruhan implikasi yang diberikan toko buku online terhadap masyarakat virtual atau khususnya konsumen pada toko buku online membawa banyak implikasi yang bernilai positif. Menariknya berdasarkan tipologi strategi kompetitif itu sendiri dimana strategi sebuah perusahan untuk mengembangkan gaya atau model pemasaran dalam beradaptasi terhadap perubahan lingkungan oleh masing-masing buku online mempunyai ciri khas tersendiri.

\section{Kesimpulan}

Promosi yang dilakukan toko buku Togamas memiliki ciri khas tersendiri. Bagaimana tag line pasti ori (original), pasti diskon, bergaransi, dan gratis sangat melekat pada toko buku Togamas. Branding yang dilakukan pihak marketing dari Togamas mampu membius target market yang memang menjadi prioritas.

Implikasi yang diberikan toko buku online terhadap masyarakat virtual atau khususnya konsumen pada toko buku online membawa banyak implikasi yang bernilai positif, antara lain sebagai berikut. 
a. Kemudahan Transaksi

1) Metode pembayaran;

2) Pengiriman;

3) Asuransi atau garansi.

b. Share Knowlegde

1) Berbagi ulasan buku atau produk;

2) Berbagi buku atau produk favorit di media sosial;

3) Testimoni.

c. Selektif Membeli

1) Dimudahkan dengan buku terkait;

2) Membandingkan harga.

\section{Saran}

Promosi yang dilakukan oleh pihak toko buku togamas melalui website sejauh ini sudah cukup baik. Namun ada beberapa hal yang memang harus diperbaiki. Sebagai contoh misalnya, penggunaan rating atau ulasan yang terdapat dalam website Togamas tidak berfungsi sebagaimana mestinya. Hal tersebut perlu segera ditindak lanjuti oleh pihak IT Togamas sebagai upaya memperbaiki branding dari nama Togamas itu sendiri dan layanan kepada pelanggan.

\section{Daftar Pustaka}

APJII. “Laporan Survei Penetrasi \& Profil Pengguna Internet Indosesia Tahun 2018." https://apjii.or.id/content/read/39/410/Hasil-Survei-Penetrasidan-Perilaku-Pengguna-Internet-Indonesia-2018. Diakses tanggal 11 November 2019 pukul 17:31 WIB.

Ghony, M. Djunaedi dan Fauzan Almansur. Metodologi Penelitian Kualitatif, Yogyakarta: Ar-Ruzz Media, 2014.

Mohd Fawzy A B, Sharuddin S H, Rajagderan S, Wan Zulkifly W Z, "E-commerce adoption and an analysis of the popular e-commerce business sites in Malaysia”, Journal of Internet Banking and Commerce. aOttawa. Vol. 23, No. 1. Apr 2018. 
Nugroho, Adi Sulistyo. E-Commerce: Teori dan Implementasi. Yogyakarta: Ekuilibra, 2016.

Open Text Corp, EDI Basics: How Successful Businesses connect, communicate, and collaborate, around the word, (opentext, 2017).

Peattie K. "The Marketing Mix in The Third Age of Computing." Emerald, Volume 15, Issue 3. https://doi.org/10.1108/02634509710165948. Diakses tanggal 20 April 2019.

Pusat Bahasa Departemen Pendidikan Nasional. Kamus Besar Bahasa Indonesia, edisi ketiga, Jakarta: Balai Pustaka, 2007.

Renaningtyas, Luri. Ruang Virtual dan Ruang Realitas. Universitas Kristen Petra, Desain Komunikasi Visual 2013.

Retnowati, Novita. "Pengaruh E-Wom (Electronic Word of Mouth) Pada Situs Social Commerce Terhadap Niat Beli Generasi X, Y, dan Z.” Tesis. Surabaya: Institut Sepuluh November, 2017.

Setiawan, Ezekiel A. "Internet, intranet, extranet: pondasi e-business mendatang: perlu ditopang pengetahuan/kesadaran akan Internet Security." Buletin Informatika. Vol. 4, No.1. Tahun 2015.

Setyadi, Rino. "Komunikasi Virtual: Sebuah Keniscayaan Masyarakat Teknologi." http:// komunikasi.us/index.php/course/4899-komunitas-virtual-sebuah-keniscayaanmasyarakat-teknologi. Diakses tanggal 15 Maret 2019 pukul 19:00 WIB.

Stanton WJ. Manajemen dan Pemasaran. Jakarta: Erlangga, 1991.

Sutanto, Ryan Pratama. "Studi Kasus Website Gramedia sebagai Media Online untuk Membeli Buku." NIRMANA. Universitas Kristen Petra Surabaya. Vol. 17, No. 1. Januari 2017.

Swastha, Basu dan Hani Handoko. Manajemen Pemasaran Analisis Perilaku Konsumen. Yogyakarta: BPFE, 1982.

Thurau et. al.. "The Impact of New Media on Customer Relationships." Journal of Service Research. Vol. 13, No. 3. Agustus 2010.

Tjipto, Fandy. Strategi Pemasaran, Yogyakarta: Andi, 1998.

Togamas. https://togamas.com/. Diakses tanggal 15 Maret 2019 pukul 19:16 WIB. Turban, Efraim et al., Electronic Commerce 2018, Springer, Tahun 2018.

We Are Social. https://wearesocial.com/global-digital-report-2019. Diakses tanggal 11 November 2019 pukul 17:00 WIB. 